\title{
Biological and Molecular Characterization of an American Sugar Beet-Infecting Beet western yellows virus Isolate
}

\author{
Monique Beuve, Institut National de la Recherche Agronomique (INRA), UMR Santé de la Vigne et Qualité du Vin \\ (SVQV), Laboratoire Virologie \& Vection, 68021 Colmar cedex, France, and Université L. Pasteur, 67000 Stras- \\ bourg, France; Mark Stevens, Broom's Barn Research Center, Higham, Bury St. Edmunds, Suffolk, IP28 6 NP, UK; \\ Hsing-Yeh Liu and William M. Wintermantel, United States Department of Agriculture-Agricultural Research \\ Station, Salinas, CA 93905; and Sébastien Hauser and Olivier Lemaire, INRA UMR SVQV, France
}

\begin{abstract}
Beuve, M., Stevens, M., Liu, H.-Y., Wintermantel, W. M., Hauser, S., and Lemaire, O. 2008. Biological and molecular characterization of an American sugar beet-infecting Beet western yellows virus isolate. Plant Dis. 92:51-60.

Three aphid-transmitted viruses belonging to the Polerovirus genus, Beet mild yellowing virus (BMYV), Beet chlorosis virus (BChV), and Beet western yellows virus (BWYV), have been described as pathogens of sugar beet. We present the complete biological, serological, and molecular characterization of an American isolate of Beet western yellows virus (BWYV-USA), collected from yellow beet leaves. The biological data suggested that BWYV-USA displayed a host range similar to that of BMYV, but distinct from those of $\mathrm{BChV}$ and the lettuce and rape isolates of Turnip yellows virus. The complete genomic RNA sequence of BWYV-USA showed a genetic organization and expression typical of other Polerovirus members. Comparisons of deduced amino acid sequences showed that P0 and the putative replicase complex (P1-P2) of BWYV-USA are more closely related to Cucurbit aphid-borne yellows virus (CABYV) than to BMYV, whereas alignments of P3, P4, and P5 showed the highest homology with BMYV. Intraspecific and interspecific phylogenetic analyses have suggested that the BWYV-USA genome may be the result of recombination events between a CABYV-like ancestor contributing open reading frame (ORF) 0, ORF 1, and ORF 2, and a beet Polerovirus progenitor providing the 3' ORFs, with a similar mechanism of speciation occurring for BMYV in Europe. Results demonstrate that BWYV-USA is a distinct species in the Polerovirus genus, clarifying the nomenclature of this important group of viruses.
\end{abstract}

Additional keywords: Beta vulgaris, cross-protection, epidemiology, Luteoviridae, Myzus persicae, RT-PCR

Luteoviruses were first recognized in 1976 as a cluster of related viruses sharing numerous common biological, structural, and biochemical features (12), and were recognized formally in 1997 by the International Committee for the Taxonomy of Viruses (ICTV) as the family Luteoviridae (2). Members of this family consist of icosahedral particles $(T=3)$ which are phloem-limited, with positive-strand RNA, and are circulatively persistently transmitted by several aphid species. There are three assigned genera within the family Luteoviridae: Luteovirus, Polerovirus, and Enamovirus, and the type species of each genus is Barley yellow dwarf virus-PAV (BYDV-PAV), Potato leafroll virus (PLRV), and Pea enation mosaic virus RNA-1 (PEMV RNA$1)$, respectively.

Corresponding author: O. Lemaire

E-mail: lemaire@colmar.inra.fr

Accepted for publication 13 August 2007.

doi:10.1094/PDIS-92-1-0051

(C) 2008 The American Phytopathological Society
In the genus Polerovirus, and more precisely within the "beet polerovirus-like" subgroup, the characterization and nomenclature of closely related virus isolates has remained somewhat unclear for a number of years. Roland (29) first implied that a virus was the causal agent of sugar beet yellows and, later, Watson (45) indicated that sugar beet yellows may be induced by a complex of different yellowing viruses. The complex taxonomic history began in 1958 when Russell (30) and Duffus (6) almost simultaneously characterized similar sugar beet yellowing viruses. Russell identified Beet mild yellowing virus (BMYV) in England, while Duffus characterized a similar sugar beet yellowing virus in the western United States; initially, this virus was called radish yellows (6) and, later, Beet western yellows virus (BWYV) (7). The American BWYV isolates caused yellowing and stunting in a large number of crop plants, including Beta vulgaris, Spinacia oleracea, Lactuca sativa, and Brassica oleracea var. italica, and had an extensive host range, including over 150 plant species from 23 dicotyledonous families (1,8,9,31). The discovery of BWYV in America led Duffus and Russell to search for BWYV in Britain. A BWYVlike virus was described in England in hosts previously reported immune to BMYV (32). These plants were shown to be infected with a virus serologically and biologically related to the American BWYV isolates (10). However, distinct differences existed between the host ranges of BMYV and European BWYV isolates. European isolates infecting sugar beet were classified as BMYV, whereas European isolates that infected a broad range of commercially important crops such as Brassica spp. (e.g., oilseed rape) and $L$. sativa, but did not infect Beta vulgaris $(36,40)$, were classified as BWYV. The difference between American and European BWYV isolates with regard to infection of sugar beet has led to considerable debate over taxonomy and relatedness among beet-infecting poleroviruses. Recently, the ICTV approved a proposal to reclassify the non-beet-infecting strains of BWYV as a separate species in the genus Polerovirus, with the name Turnip yellows virus (TuYV) (18).

Discrimination between sugar beet infecting and non-beet-infecting Polerovirus isolates is of particular importance in the study of the epidemiology of virus yellows disease of sugar beet as well as for conventional breeding and transgenic resistance programs. Polyclonal antisera raised against either BMYV or European BWYV do not discriminate between these poleroviruses. However, a monoclonal antibody (Mab) raised against BYDV-PAV-IL-1 enables this serological distinction (3). More recently, biological, serological, and molecular characterization of BMYV and of a European L. sativa-infecting isolate of TuYV (formerly BWYV-FL1) (44) has confirmed that BMYV and European TuYV are two distinct virus species $(13,16)$. Comparison of nucleotide sequence data, deduced amino acid sequences, and phylogenetic analyses of a number of geographically distinct beet Polerovirus isolates originating from various countries identified specific molecular clusters within the coat protein $(\mathrm{CP})$ region that were highly conserved among poleroviruses isolated from the same plant species (4) (greater than $90 \%$ similarity). In contrast, the P0 sequences (open reading frame $[\mathrm{ORF}] 0$ ) were highly variable. Both 
Hauser et al. (15) and Stevens et al. (39) studied more precisely this grouping of the $\mathrm{CP}$ by testing additional isolates, and identified five clusters that corresponded to biologically or geographically distinct beet poleroviruses. Sequence analysis of $\mathrm{P} 0$ and biological properties, especially in the hosts Capsella bursa-pastoris and Chenopodium capitatum, enabled a clear distinction to be made between the TuYV rape or lettuce isolates and the BMYV beet isolates (17). This eventually led to the identification of Beet chlorosis virus (BChV) as a new species within the Polerovirus genus (18). BChV has been fully sequenced (14) and has the genomic organization of a typical Polerovirus. Within the Polerovirus genus, there are three beet-infecting species: BMYV, BChV, and BWYV $(37,38)$. In this article, we present, for the first time, the full molecular characterization of an American sugar beet-infecting BWYV isolate (BWYV-USA) and its phylogenetic relationships among the members of the family Luteoviridae, as well as its biological properties. Such molecular and biological data will help to resolve key taxonomic questions and to confirm the status of BWYV-USA as a distinct virus species within the genus Polerovirus, family Luteoviridae. It also will enable the further development of molecular tools to discriminate among the beet poleroviruses and to characterize the modular evolution of the virus species within the genus Polerovirus.

\section{MATERIALS AND METHODS}

Virus strains, transmission, and host range. The isolate of BWYV kindly supplied by Dr. Gail Wisler (United States Department of Agriculture-Agricultural Research Station [USDA-ARS], Salinas, CA) and used throughout this work was collected from a sugar beet plant growing in California which exhibited mild yellow symptoms. This isolate was called BWYVUSA to differentiate it from European biotypes of TuYV (formerly BWYV). The isolate was maintained in Colmar on $B$. vulgaris (cv. Trestel) by serial transmission using individual wingless Myzus persicae (clone NL, kindly supplied by Dr. D. Peters). BMYV-2ITB and BChV-2a were collected in France and England, respectively, from infected sugar beet and maintained on B. vulgaris (cv. Trestel). The TuYV-FL1 (formerly BWYV-FL1) lettuce isolate was propagated on Physalis floridana and TuYV-Col was propagated on Brassica napus (cv. Jet 9). Additionally, 11 samples collected in Colorado and California from symptomatic sugar beet were frozen $\left(-20^{\circ} \mathrm{C}\right)$ in aliquots of $100 \mathrm{mg}$ prior to total RNA extraction and reversetranscriptase polymerase chain reaction (RT-PCR) experiments.

For host range analysis performed in Colmar, viruliferous $M$. persicae (clone $\mathrm{NL}$ ) colonies were maintained on beet plants (Beta vulgaris cv. Trestel) infected with either BMYV-2ITB, BChV-2a, or BWYV-USA or on TuYV-FL1-infected Raphanus sativus or TuYV-Col-infected Brassica napus (cv. Jet 9). Ten wingless aphids (fourth-instar nymphs and adults) were transferred to six to eight healthy test plants at the three- to four-leaf stage for an inoculation access period (IAP) of 4 days; the plants then were sprayed with an insecticide (Mevinphos at $4 \mathrm{ml} /$ liter). Plants were grown at $20^{\circ} \mathrm{C}$ in a climatic cabinet with a 16-h photoperiod and a light intensity of 3,000 lux. Infection was determined at 3 and 6 weeks post inoculation (wpi) by enzyme-linked immunosorbent assay (ELISA) and RT-PCR. Mock inoculations were made using non-viruliferous $M$. persicae (clone NL) reared on Beta vulgaris (cv. Trestel).

For host range analysis performed in Salinas, apterous $M$. persicae (Salinas clone), were given a 48-h acquisition access period (AAP) on B. vulgaris (cv. Trestel) source plants infected with either BWYV-USA or BChV isolates (BWYVUSA-Sal and BChV-Sal, respectively) and then transferred in groups of 10 to test plants for a 24-h IAP, after which aphids were sprayed with Orthene PT-1300 (Whitmire Micro-Gen Inc., St. Louis). Approximately 6 wpi, $10 \mathrm{M}$. persicae again were used to transmit the Polerovirus isolates back to indicator plants (Capsella bursa-pastoris and Chenopodium capitatum), which were assayed by doubleantibody sandwich (DAS)-ELISA 3 weeks later to ascertain that no crosscontamination occurred between experiments. Mock inoculations also were performed with virus-free aphids to confirm that the vector populations were not viruliferous.

Cross-protection experiments. Reciprocal cross-protection experiments were performed using BWYV-USA and BMYV2ITB as challenging and protecting viruses. B. vulgaris (cv. Trestel) seedlings at the three- to four-leaf stage were inoculated with 10 viruliferous $M$. persicae containing either BWYV-USA or BMYV2ITB as the protective virus. Five plants per condition were used: plants in the first set were inoculated with either BWYVUSA or BMYV-2ITB alone and plants in the second set were doubly inoculated with the two viruses at intervals, the first being the protecting virus and the second the challenging virus. In experiments where a second inoculation was required, the first batch of viruliferous $M$. persicae was destroyed manually. Plants were exposed to viruliferous $M$. persicae at 7,14 , and 21 days following the first transmission, and then sprayed 3 days later (Mevinphos at 4 $\mathrm{ml} /$ liter). Sugar beet plants were kept in a climatic cabinet in the same conditions as above and five plants from each experiment were assessed randomly by tripleantibody sandwich (TAS)-ELISA, using
MAFF24 and PAV-IL-1 (this antibody detects BMYV specifically), and by RTPCR using virus-specific primers (BM1+/MpxBM1- and LewP0+/SP1-) 3 and 6 weeks after the second inoculation in order to detect BMYV and BWYV-USA, respectively, in the doubly infected plants. BM1+/MpxBM1- primers located respectively at nucleotides 32 to 55 and 453 to 472 on BMYV-2ITB genome X83110 generated an RT-PCR amplicon of $441 \mathrm{bp}$. LewP0+/SP1- primers located at nucleotides 64 to 84 and 288 to 307 on BWYVUSA genome NC_004756 generated an RT-PCR amplicon of $244 \mathrm{bp}$.

Infection of test plants was monitored 3 and 6 wpi by TAS-ELISA using monoclonal antibody MAFF 24 or PAV-IL-1. MAFF 24 was raised against the BMYV-1 isolate from England and utilized as previously described (27,35). Mab MAFF 24 was diluted at $0.5 \mu \mathrm{g} / \mathrm{ml}$ in phosphatebuffered saline-Tween-polyvinylpyrrolidone with $0.1 \%$ dry milk, and anti-rat alkaline phosphatase conjugate was used at $1 / 1,000$ dilution as previously described (35). Mab PAV-IL-1 (raised against a BYDV-PAV isolate from Illinois; 3) was assessed using an anti-mouse alkaline phosphatase conjugate similarly as above. Threshold values were calculated as usual (14).

To compare virus levels in doubly and singly inoculated sugar beet and, therefore, assess the degree of cross-protection between BMYV and BWYV-USA, the double to single $(\mathrm{D} / \mathrm{S})$ infection ratio was calculated. However, due to the lack of specific detection of BWYV-USA by ELISA, we determined the D/S ratio only when BMYV acted as the challenging virus and BWYV-USA as the protecting strain. The D/S ratio for BMYV was defined as ([mean BMYV optical density at $405 \mathrm{~nm}$ (OD) values for doubly infected plants - mean OD values for healthy plants]/[mean BMYV OD values for singly infected plants - mean OD values for healthy plants]). Thus, if the replication of challenging virus is inhibited by the protecting virus, the $\mathrm{D} / \mathrm{S}$ ratio should be less than 0.1 . In case of no cross-protection, the $\mathrm{D} / \mathrm{S}$ ratio should be above 0.5 .

Virion purification and RNA extraction. Virion purifications were performed using infected $S$. oleracea leaves 8 wpi as previously described (14). The PUREscript kit (GENTRA Systems Inc., Minneapolis, $\mathrm{MN}$ ) protocol was adapted for the extraction of total RNA either from infected plants (100 mg of fresh leaf tissue) or from viral genomic RNA as previously described (14). RNA was resuspended in diethylpyrocarbonate (DEPC)-treated water and stored at $-20^{\circ} \mathrm{C}$ or used immediately.

Complementary DNA synthesis, 5' and $3^{\prime}$ rapid amplification of cDNA ends by PCR, and DNA cloning. Complementary DNA (cDNA) was synthesized from 
purified RNA extracted from frozen infected B. vulgaris (cv. Trestel) leaves as previously described (14). For $5^{\prime}$ and $3^{\prime}$ rapid amplification of cDNA ends (RACE), viral RNA was obtained from a purified preparation of BWYV-USA virions. RNA was tailed at the $3^{\prime}$ end with a poly-A polymerase (Roche Molecular Biochemicals, Meylan, France) following the manufacturer's instructions. This polyadenylated RNA was purified with the Qiagen RNeasy Plant Mini Kit (Qiagen, Courtaboeuf, France) before synthesis of 3' cDNA. 5' cDNA was obtained with the SP1 primer, and was purified with the QIAquick
PCR Purification Kit (Qiagen) before the addition of a homopolymeric A tail using terminal transferase (Roche Molecular Biochemicals). PCR reactions (33) were carried out as previously described (14).

Purified and concentrated RT-PCR products were cloned into the plasmid vector pBluescript II SK(+) from the PCRScript Amp Cloning Kit (Stratagene, Amsterdam, The Netherlands), following the manufacturer's instructions. For $5^{\prime}$ and $3^{\prime}$ RACE, crude PCR products were cloned into the pCR 4-TOPO plasmid (Invitrogen, Paisley, UK) following the manufacturer's instructions. PCR then was performed on the selected recombinant plasmids for direct sequencing of the amplified product.

Sequencing and computer-assisted sequence analyses and phylogenetic studies. Clones were sequenced on both strands as previously described (14). Three clones for each cDNA were sequenced to ensure consistent and reliable sequence data. For 5' and 3' RACE, 10 and 8 PCR products were sequenced, respectively.

Nucleotide sequence data were assembled as previously described (14) and analyzed using Vector NTI software (Infor-

Table 1. Comparative host range of Beet western yellows virus (BWYV)-USA with four Polerovirus isolates performed either in Colmar or in Salinas laboratories $^{\mathrm{a}}$

\begin{tabular}{|c|c|c|c|c|c|}
\hline Host $^{b}$ & BWYV-USA/BWYV-USA-Sal & BMYV-2ITB & BChV-2a/BChV-Sal & TuYV-FL1 & TuYV-Col \\
\hline \multicolumn{6}{|l|}{ Aizoaceae } \\
\hline Tetragonia expansa* & + & + & + & + & $\mathrm{nt}$ \\
\hline \multicolumn{6}{|l|}{ Amaranthaceae } \\
\hline Gomphrena globosa* & + & + & + & + & $\mathrm{nt}$ \\
\hline \multicolumn{6}{|l|}{ Asteraceae } \\
\hline Chrysanthemum coreanum* & + & - & - & $\mathrm{nt}$ & $\mathrm{nt}$ \\
\hline Cichorium endivia* & $\mathrm{nt}$ & - & nt & $\mathrm{nt}$ & $\mathrm{nt}$ \\
\hline Lactuca sativa & + & - & - & + & - \\
\hline Senecio vulgaris & + & + & - & + & - \\
\hline Zinnia elegans* & + & + & + & + & $\mathrm{nt}$ \\
\hline \multicolumn{6}{|l|}{ Boraginaceae } \\
\hline Amsinckia douglasiana* & + & $\mathrm{nt}$ & + & + & $\mathrm{nt}$ \\
\hline \multicolumn{6}{|l|}{ Brassicaceae } \\
\hline Brassica napus cv. Goeland & - & - & - & - & + \\
\hline Brassica napus USA* & + & $\mathrm{nt}$ & - & $\mathrm{nt}$ & $\mathrm{nt}$ \\
\hline Capsella bursa-pastoris & + & + & - & + & + \\
\hline Crambe abyssinica & + & + & - & + & + \\
\hline Lepidium nitidum* & + & - & $\mathrm{nt}$ & + & $\mathrm{nt}$ \\
\hline Thlaspi arvense* & + & - & - & + & $\mathrm{nt}$ \\
\hline Raphanus sativus* & + & - & + & + & $\mathrm{nt}$ \\
\hline Sinapis alba & + & + & - & + & + \\
\hline \multicolumn{6}{|l|}{ Caryophyllaceae } \\
\hline Spergula arvensis & + & + & $-\mathrm{t}$ & + & + \\
\hline Stellaria media & + & + & - & + & + \\
\hline \multicolumn{6}{|l|}{ Chenopodiaceae } \\
\hline Beta vulgaris & + & + & + & + & - \\
\hline Chenopodium capitatum & - & - & + & - & - \\
\hline Spinacia oleracea & + & + & + & + & + \\
\hline \multicolumn{6}{|l|}{ Cucurbitaceae } \\
\hline Cucurbita pepo & $-\mathrm{t}$ & + & - & - & - \\
\hline \multicolumn{6}{|l|}{ Malvaceae } \\
\hline Lavatera trimestris* & + & $\mathrm{nt}$ & - & $\mathrm{nt}$ & $\mathrm{nt}$ \\
\hline Malope trifida* & + & nt & - & nt & nt \\
\hline \multicolumn{6}{|l|}{ Papilionaceae } \\
\hline Medicago hispida* & + & $\mathrm{nt}$ & - & $\mathrm{nt}$ & $\mathrm{nt}$ \\
\hline Pisum sativum* & + & nt & - & nt & $\mathrm{nt}$ \\
\hline \multicolumn{6}{|l|}{ Portulacaceae } \\
\hline Montia perfoliata & + & + & - & + & + \\
\hline \multicolumn{6}{|l|}{ Solanaceae } \\
\hline Capsicum апиит* & + & $\mathrm{nt}$ & - & $\mathrm{nt}$ & $\mathrm{nt}$ \\
\hline Datura stramonium* & + & $\mathrm{nt}$ & - & $\mathrm{nt}$ & $\mathrm{nt}$ \\
\hline Lycopersicon esculentum* & + & $\mathrm{nt}$ & - & nt & $\mathrm{nt}$ \\
\hline Nicotiana clevendii* & + & $\mathrm{nt}$ & - & $\mathrm{nt}$ & nt \\
\hline Nierembergia frulea* & + & nt & - & nt & nt \\
\hline Physalis floridana* & + & nt & - & nt & $\mathrm{nt}$ \\
\hline P. wrightii* & + & $\mathrm{nt}$ & - & $\mathrm{nt}$ & $\mathrm{nt}$ \\
\hline Schizanthus pinnatus* & + & $\mathrm{nt}$ & - & nt & $\mathrm{nt}$ \\
\hline S.wisefonensis* & + & $\mathrm{nt}$ & nt & $\mathrm{nt}$ & $\mathrm{nt}$ \\
\hline Solanum nigrum* & + & $\mathrm{nt}$ & nt & $\mathrm{nt}$ & nt \\
\hline S. polytrichon* & + & $\mathrm{nt}$ & $\mathrm{nt}$ & $\mathrm{nt}$ & nt \\
\hline
\end{tabular}

a Abbreviations: Beet mild yellowing virus (BMYV), Beet chlorosis virus $(\mathrm{BChV})$, and Turnip yellows virus $(\mathrm{TuYV}) ;+=\mathrm{host},-=\mathrm{nonhost},-\mathrm{t}=\mathrm{transient}$ infection, and $\mathrm{nt}=$ not tested.

${ }^{\mathrm{b}}$ Host range experiments were performed in the Colmar and Salinas laboratories, indicated with a asterisk (*) after host name species. We presented neither the transmission rates nor the enzyme-linked immunosorbent assay (ELISA) readings, but only the quality of host or nonhost for each plant species. A positive score indicates at least one infected plant detected either by ELISA at 3 and 6 weeks post inoculation (wpi), directly on the test plants or after backtransmission by Myzus persicae to Capsella bursa pastoris and Chenopodium capitatum for the Salinas host range tests. A transient infection means weak ELISA readings 3 wpi followed by a negative result 6 wpi. 
max, North Bethesda, MD). Phylogenetic relationships between the BWYV-USA, the beet poleroviruses, and other Luteoviridae sequences were assessed using ClustalX (42) and phylogenetic trees were drawn using neighbor-joining methods (11). To assess the statistical significance of the trees, bootstrap values were calculated on 1,000 replicates. The genomic sequences (virus and accession number) used in the alignment studies were Bean leaf roll virus (BLRV) (U15978), BChV (AF352024), BMYV-2ITB (X83110), TuYV-FL1 (X13062), TuYV-L (Y11531), BYDV-PAV (X07653), Cereal yellow dwarf virus (CYDV-RPV-NY) (NC001599), Chickpea stunt disease associated virus (ChPSt) (Y11530), Cucurbit aphid-borne yellows virus (CABYV) (X76931), Groundnut rosette assistor virus (GRAV) (Z68894), PEMV-1 (L04573), PLRV (Y07496), Southern bean mosaic virus (SbMV, Sobemovirus) (AF055888), Soybean dwarf virus (SbDV) (AB038148), Sugarcane yellow leaf virus (ScYLV) (AF157029), and Turnip yellows virus (TuYV-GB) (AF167486).

\section{RESULTS}

Host range analysis. In all, 38 plant species from 12 families were assayed to determine the host range of BWYV-USA in comparison with BMYV-2ITB, BChV2a, TuYV-FL1, and TuYV-Col (Table 1) using $M$. persicae as the virus vector. RTPCR was used to confirm that no crosscontamination had occurred between virus strains (data not shown). The lettuce strain of TuYV-FL1 was able to infect $24 \%$ of inoculated sugar beet plants (out of 50 plants tested) $3 \mathrm{wpi}$, with an OD value of twice the ELISA threshold. In the same experiment, BMYV- and BChV-infected plants displayed OD values at least 10 times greater than the ELISA threshold, with $100 \%$ of sugar beet infected 3 weeks after infection using the $M$. persicae Colmar clone. Four weeks later, ELISA testing of the same plants identified only 1 of 50 sugar beet plants positive for TuYV-FL1, whereas the number of plants testing positive was maintained for BWYV-USA, BMYV, and BChV. This interaction between sugar beet and TuYV-FL1 was observed consistently and correlated with the absence of any yellowing symptoms. BMYV, BChV, and BWYV-USA all induced typical symptoms of mild yellowing disease 10 wpi under high-intensity light conditions (16-h light period, over 3,000 lux). Cucurbita pepo was shown for the first time to be a host of BMYV-2ITB ( $94 \%$ infection rate), whereas only $15 \%$ of $C$. pepo plants became infected with BWYV-USA. Two Brassica napus cultivars were assayed and displayed differential rates of infection toward BWYV-USA. The French B. napus cv. Goéland was shown to be a nonhost in all current and previous experiments (15) toward BWYVUSA, BMYV, BChV, and TuYV-FL1, but susceptible to TuYV-Col. Conversely, an American B. napus cultivar was shown to be susceptible to BWYV-USA, indicating some variability of infection with BWYVUSA among $B$. napus cultivars. Besides Beta vulgaris, five plant species appear to be common hosts and could serve as reservoirs for the four Chenopodiaceaeinfecting Polerovirus spp.: Spergula arvensis, Spinacia oleracea, Gomphrena globosa, Tetragonia expansa, and Zinnia elegans.

Cross-protection experiments and specific detection of BWYV-USA. To analyze the degree of cross-protection between BWYV-USA and BMYV, we performed TAS-ELISA (Table 2) and RTPCR (Fig. 1) to ensure the specific detection of each protecting and challenging virus. Monoclonal antibody PAV-IL1 reacted only with BMYV but not with BWYV-USA, whereas Mab MAFF 24 detected both viruses (Table 2). The serological properties of the two virus species enabled calculation of the D/S ratio only when BMYV was used as challenging virus and BWYV-USA as protecting strain, because no reciprocal ELISA tests could be performed to obtain specific BWYVUSA OD values for the mixed infection. No cross-protection effect or mutual inhibition between the challenging and protecting poleroviruses was observed in the three inoculation intervals when BWYVUSA was used as protecting virus. Additionally, we calculated the D/S ratio (OD values of doubly infected on singly infected plants; 46) to assess more accurately the possible degree of crossprotection between the viruses, to determine whether the replication of one virus could be inhibited by the protecting virus. If this was the case, the $\mathrm{D} / \mathrm{S}$ ratio would be close to 0 . The $\mathrm{D} / \mathrm{S}$ ratios calculated for BMYV as the challenger ranged between 0.7 and 1.3 (Table 2), confirming no protective effect when BWYV-USA was used as protector.

RT-PCR assays determined that both RNA species could be detected in the challenged plants. Using primer pairs BM1+/MpxBM1- and LewP0+/SP1- (Table 3) to specifically detect ORF 0 of BMYV and BWYV-USA, respectively, amplicons of approximately 450 and 250 bp were observed using the mutliplex RTPCR procedure (Fig. 1). Regardless of when BMYV or BWYV-USA was used as protective or challenger virus, ORF 0 of both poleroviruses was detected, suggesting a similar level of replication, expression, and movement of both viruses in sugar beet. In addition, this experiment indicated the potential of using primers designed within ORF 0 to differentiate BWYV-USA from BMYV-2ITB in diagnostic and epidemiological studies.

Using the four primer pairs $\mathrm{CP}+/ \mathrm{CP}-$, $\mathrm{BM} 1+/ \mathrm{MpxBM} 1-, \mathrm{MpxBC}+/ \mathrm{MpxBC}-$, and LewP0+/SP1- (Table 3), giving RT-PCR amplicons of 560, 450, 350, and $250 \mathrm{bp}$, respectively, corresponding to parts of the $\mathrm{CP}$ gene of beet poleroviruses and parts of the BMYV, BChV, and BWYV-USA ORF 0 , respectively, 4 of 11 samples collected in California and Colorado were found to

Table 2. Virus levels estimated by enzyme-linked immunosorbent assay (ELISA) mean values and double to single infection (D/S) ratio (in parentheses), in cross-protection between Beet western yellows virus (BWYV)-USA and Beet mild yellowing virus (BMYV)-2ITB

\begin{tabular}{|c|c|c|c|c|c|}
\hline \multirow[b]{3}{*}{ Viruses inoculated protector/challenger } & \multirow[b]{3}{*}{ Inoculation interval (days) } & \multicolumn{4}{|c|}{ OD values (D/S ratio) at time after challenge inoculation ${ }^{a}$} \\
\hline & & \multicolumn{2}{|c|}{ PAV IL1 } & \multicolumn{2}{|c|}{ MAFF 24} \\
\hline & & 20 days & 40 days & 20 days & 40 days \\
\hline BMYV-2ITB (T0) & $\ldots$ & 1.6 & 1.36 & 0.39 & 1.71 \\
\hline BWYV-USA (T0) & $\ldots$ & 0.12 & 0.1 & 0.37 & 1.46 \\
\hline BMYV-2ITB (T21) & $\ldots$ & 1.66 & 1.21 & 0.75 & 1.78 \\
\hline BWYV-USA (T21) & $\ldots$ & 0.12 & 0.1 & 0.5 & 2.02 \\
\hline BMYV-2ITB / BWYV-USA & 7 & 1.55 & 1.33 & $\mathrm{nt}$ & $\mathrm{nt}$ \\
\hline BWYV-USA / BMYV-2ITB & 7 & $1.24(0.7)$ & $1.26(1)$ & nt & $\mathrm{nt}$ \\
\hline BMYV-2ITB / BWYV-USA & 14 & 1.91 & 1.52 & nt & nt \\
\hline BWYV-USA / BMYV-2ITB & 14 & $1.78(1.1)$ & $1.06(0.8)$ & $\mathrm{nt}$ & $\mathrm{nt}$ \\
\hline BMYV-2ITB / BWYV-USA & 21 & 1.91 & 1.26 & $\mathrm{nt}$ & $\mathrm{nt}$ \\
\hline BWYV-USA / BMYV-2ITB & 21 & $2.02(1.3)$ & $1.24(1)$ & nt & $\mathrm{nt}$ \\
\hline
\end{tabular}

${ }^{a}$ Means of $405 \mathrm{~nm}$ optical density (OD) readings at $30 \mathrm{~mm}$ from five plants. Positive OD values are in bold; $\mathrm{nt}=$ not tested. The D/S ratio for BMYV as challenging virus was determined as (mean ELISA value for doubly infected plants - mean ELISA value for healthy plants)/(mean ELISA value for singly infected plants - mean ELISA value for healthy plants). A D/S ratio below 0.1 is an indication of cross-protection between the two viruses. The DS ratio is presented in parentheses. 
be infected with BWYV-USA and 7 samples with BChV.

Complete genomic sequence of BWYV-USA. To obtain cDNAs of BWYV-USA, RNA was extracted from either BWYV-USA-infected sugar beet or from virions purified from infected spinach (for RACE procedures). Ten RT-PCR clones were synthesized (Fig. 2) using primers designed to the BMYV-2ITB sequence (13) for the $3^{\prime}$ half of the genome (Table 3). Poleroviruses share limited homology within the $5^{\prime}$ proximal region of ORF 0 and the first half of ORF 1 (20). Analysis of the amino acid sequences of
TuYV-FL1, BMYV, PLRV, CABYV, and $\mathrm{BChV}$ revealed the presence of a conserved peptide motif, GPPNWE, located on P1 at nucleotide 1,010. On the assumption that this motif is conserved within the Polerovirus genus, we used a degenerate antisense primer, 8245 , to prime reverse transcription. Primer 8235 (Fig. 2) is a degenerate sense primer complementary to the first 14 residues of the $5^{\prime}$ terminus of BChV, TuYV-FL1, PLRV, and CABYV. The BWYV-USA 5' DNA fragment, which corresponds to the first 1,042 nucleotides (nt) of the $5^{\prime}$ termini of the genome, was synthesized by RT-PCR using the above primers kindly provided by Dr. H. Guilley (Institut de Biologie Moléculaire des Plantes, Strasbourg, France). Overlapping RTPCR products were synthesized using primers encompassing the above $5^{\prime}$ end clone and assembled as a contiguous sequence. The sequences of the 10 clones were aligned using Contig Manager (DNAsis package, Hitachi) and provided a sequence of 5,666 nt. Genome walking using $5^{\prime}$ and $3^{\prime}$ RACE gave 10 and 8 PCR products, respectively, which were sequenced, aligned, and assembled to the DNA sequence deduced previously. The complete nucleotide sequence $(5,666 \mathrm{nt})$

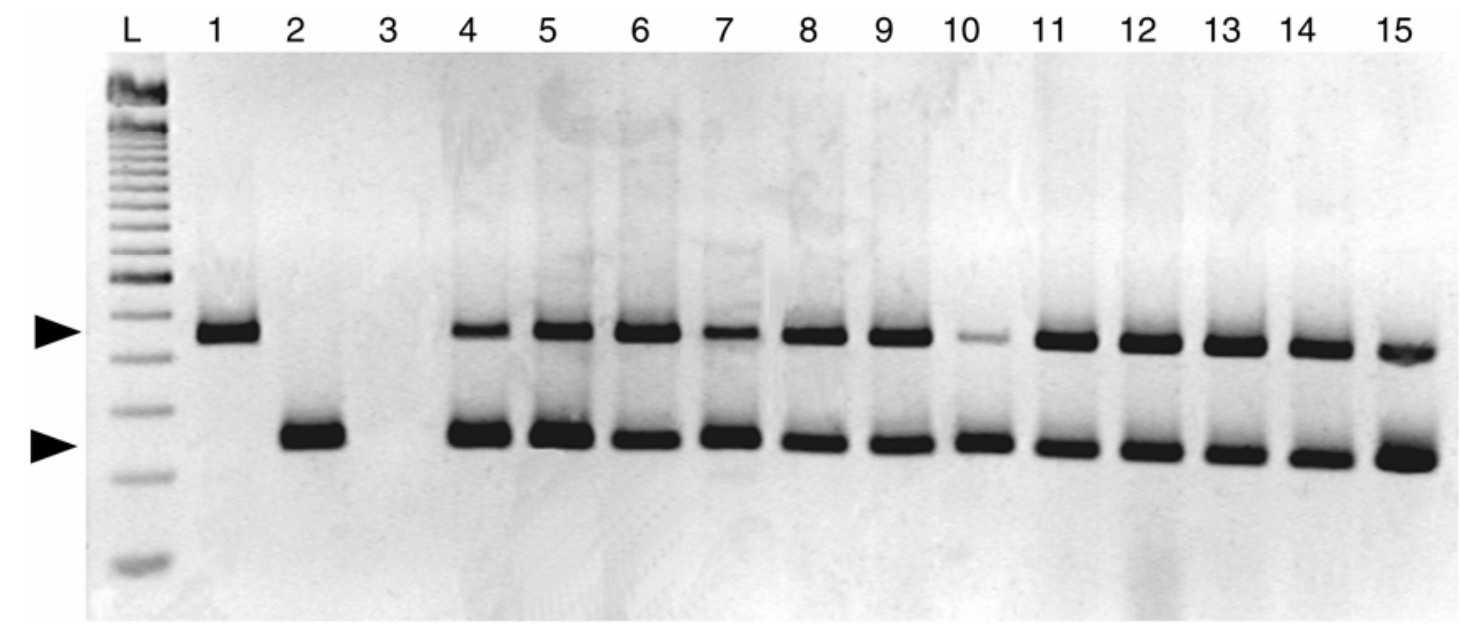

Fig. 1. Detection of Beet mild yellowing virus (BMYV)-2ITB and Beet western yellows virus (BWYV)-USA by multiplex reverse-transcriptase polymerase chain reaction (RT-PCR) in cross-protection experiment. Multiplex RT-PCR was performed using primers specific for BMYV-2ITB and BWYV-USA (primers BM1+/MpxBM1- to detect BMYV-2ITB and primers LewP0+/SP1 to detect BWYV-USA), generating amplicons of approximately 450 and 250 bp, respectively. Lane L corresponds to DNA size markers (100 bp; Gibco-BRL). Lanes 1 and 2, single-infection with BMYV-2ITB and BWYV-USA, respectively; lane 3, noninfected beet; lanes 4 to 9, co-infections with BMYV-2ITB as protective virus and BWYV-USA as challenger virus with inoculation interval of 7 days (lanes 4 and 5), 14 days (lanes 6 and 7), and 21 days (lanes 8 and 9); lanes 10 to 15, co-infections with BWYV-USA as protective virus and BMYV-2ITB as challenger virus with inoculation interval of 7 days (lanes 10 and 11), 14 days (lanes 12 and 13), and 21 days (lanes 14 and 15).

Table 3. Primers used in the molecular characterization of Beet western yellows virus (BWYV)-USA and specific detection of the beet poleroviruses ${ }^{\mathrm{a}}$

\begin{tabular}{|c|c|c|c|}
\hline Name & Sequence $5^{\prime}-3^{\prime}$ & Length & Target virus and $\mathrm{ORF}^{\mathrm{b}}$ \\
\hline 8235 & AAACGCGTCGACAAAAGAWWMSMG & 24 & BWYV-USA 5' end \\
\hline 8245 & GCTCTAGAGGATCCYTCCCARTTNGGNGGNCC & 32 & BWYV-USA ORF1 \\
\hline Anchor & GACCACGCGTATCGATGTCGAC & 22 & BWYV-USA $5^{\prime}$ end \\
\hline $\mathrm{BM} 1+$ & ATGCAATTTCAGCTTAAAACAAAC & 24 & BMYV ORF0 \\
\hline $\mathrm{CP}-$ & CCAGCTATCGATGAAGAACCATTG & 24 & Beet polerovirus ORF3 \\
\hline $\mathrm{CP}+$ & ATGAATACGGTCGTGGGTAGGAG & 23 & Beet polerovirus ORF3 \\
\hline $\mathrm{CP}+\mathrm{rev}$ & CTCCTACCCACGACCGTATTCAT & 23 & BWYV-USA ORF3 \\
\hline Frd3 & ATTGCTCYGGTTTTGACTGGAG & 22 & BWYV-USA ORF2 \\
\hline Frd4 & GACGTTGCCAAGGACCAATT & 20 & BWYV-USA ORF4 \\
\hline LewP0+ & CAGAGCTAATCGTTTCTTGAC & 21 & BWYV-USA ORF0 \\
\hline MpxBM1- & GCTTTCAGCACACCATACTG & 20 & BMYV ORF0 \\
\hline $\mathrm{MpxBC}+$ & ATGAACTTTGAGATTTGCTTC & 21 & BChV ORF0 \\
\hline MpxBC- & TGACAGCTTTTTCTGAAGAG & 20 & BChV ORF0 \\
\hline P1 fwd & GGTCTTTTGACCGCACAACATG & 22 & BWYV-USA ORF1 \\
\hline P1-2 fwd & CTTGCCGAGAAGGCAATGAAG & 21 & BWYV-USA ORF2 \\
\hline P1-2 rev & CATCGGTAGAGGGAGCTGAAG & 21 & BWYV-USA ORF2 \\
\hline Rev3 & CTCCAGTCAAAACCRGAGCAAT & 22 & BWYV-USA ORF2 \\
\hline Rev45 & TCTCCCAGGTTGAGACTGCC & 20 & BWYV-USA ORF5 \\
\hline Rev5 & ACACCGAAGTGCCGTAGGGA & 20 & BWYV-USA ORF5 \\
\hline SP1- & TGCGCCTGAGGAATGTAATG & 20 & BWYV-USA ORF0 \\
\hline SP3 & ACATAACGGAAGTCCCCTTG & 20 & BWYV-USA ORF0 \\
\hline SP5 & CGGAGAAGCTTGCTAAGCTCA & 21 & BWYV-USA ORF5 \\
\hline $\mathrm{XCP}+$ rev & TGCCTGCGTGGTCGTCTTC & 19 & BWYV-USA ORF3 \\
\hline XFrd3 & CAACTGATTAGTGATTGGAGG & 21 & BWYV-USA ORF2 \\
\hline
\end{tabular}

a Sequences of primers used for reverse-transcriptase polymerase chain reaction, rapid amplification of $\mathrm{cDNA}$ ends, and detection experiments; $\mathrm{W}=\mathrm{A}$ or $\mathrm{T}$, $\mathrm{M}=\mathrm{A}$ or $\mathrm{C}, \mathrm{S}=\mathrm{C}$ or $\mathrm{G}, \mathrm{Y}=\mathrm{C}$ or $\mathrm{T}$, and $\mathrm{R}=\mathrm{A}$ or $\mathrm{G}$.

${ }^{\mathrm{b}} \mathrm{ORF}=$ open reading frame, $\mathrm{BMYV}=$ Beet mild yellowing virus, and $\mathrm{BChV}=$ Beet chlorosis virus . 
of the BWYV-USA genomic RNA has been assigned the accession number NC_004756 in the National Center for Biotechnology Information database.

Genomic organization of BWYVUSA. Analysis of the distribution of translation initiation and termination codons suggested the presence of six long ORFs in the positive strand. The genetic organization of the six ORFs is typical of other Polerovirus members. The $3^{\prime}$ noncoding region (NCR) of BWYV-USA is $126 \mathrm{nt}$ in length and displays significant sequence homology with BChV, BMYV, TuYV-FL1, and CABYV. The $5^{\prime}$ NCR of the genomic RNA is short (29 residues) and the first eight residues at the $5^{\prime}$ terminus (5'ACAAAAGA) are identical among BChV, BMYV, TuYV-FL1, and CABYV.

Pairwise comparison of BWYV-USA proteins within Polerovirus spp. and phylogenetic relationships among members of the Luteoviridae family. Comparison of the P0, P1, and P2 amino acid sequences of beet and cucurbit infecting poleroviruses (Fig. 3A) indicate that CABYV, BWYV-USA, and BMYV exhibit the highest percentages of similarity within the $5^{\prime}$ portion of the genome. Percentage identity for $\mathrm{P} 0$ among these three viruses was approximately $50 \%$ for this highly variable ORF. Nucleotide identity decreased to around $20 \%$ when the $\mathrm{P} 0$ of BWYV-USA was compared with those of BChV and TuYV-FL1. In the 3' portion of the genome, which starts near the initiation codon of ORF 3, sequences are highly conserved among Polerovirus spp., ranging from 86 to $100 \%$ identity (Fig. 3B).

Phylogenetic trees were deduced and constructed using ClustalX and the neighbor-joining method (Fig. 4). Bootstrap values based on 1,000 replicates are shown. The 5' end phylogeny demonstrated that BWYV-USA P0 and $\mathrm{P} 1+\mathrm{P} 2$ groups represent significantly different clusters within the Polerovirus genus, especially with the beet Polerovirus spp., as supported by the bootstrap values (984 and 1,000 , respectively). The $\mathrm{P} 0$ and $\mathrm{P} 1+\mathrm{P} 2$ clusters of BWYV-USA and of CABYV are the closest among the members of Luteoviridae analyzed. The $\mathrm{P} 1+\mathrm{P} 2$ replicase complex of BWYV-USA shows affinity to those species within the Sobemovirus genus, and the structural proteins can be clearly divided into five distinct groups.

\section{DISCUSSION}

The work reported here has extended the knowledge of the biology and molecular features of a well-known group of poleroviruses common in North America and Europe, and has shed light on the nomen- clature of these biologically and serologically related viruses. According to the ICTV, a virus species is represented by a "replicating lineage" that occupies a particular ecological niche (43). Virus populations display features that distinguish them from other organisms; their mutation rates are $10^{4}$ to $10^{5}$ time greater than that of prokaryotes and eukaryotes, their large population size $\left(10^{11}\right.$ to $10^{12}$ of Tobacco mosaic virus [TMV] particles in a single tobacco leaf), and their short generation times all contribute to their complex diversity and dynamic taxonomic status (23). Therefore, several criteria must be used to distinguish between the genomic and phenotypic variability within a quasi-species and a new virus species. Because a particular quasi-species is characterized by a cloud of sequences with continual genomic variation, phylogeny is not sufficient to enable species distinction; biological and serological properties are needed to confirm virus species identity.

Biological properties of BWYV-USA. Under controlled conditions, BWYV-USA induced typical mild yellowing symptoms on sugar beet, similar to those observed in the field. However, BWYV-USA exhibited more severe yellowing symptoms on the sugar beet cultivars used in our experiments than BMYV-2ITB. Similarly, symp-

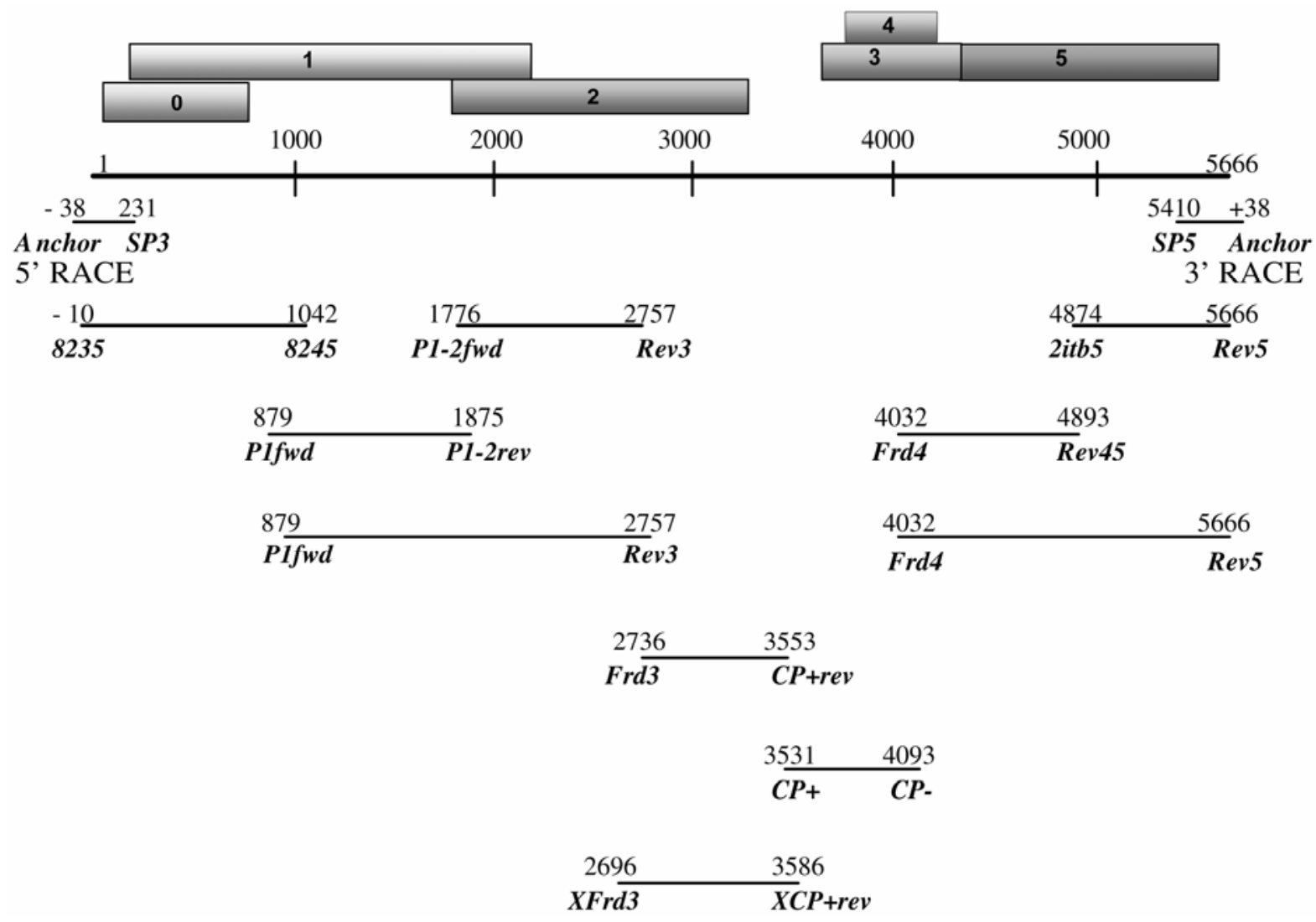

Fig. 2. Schematic representation of the cloning strategy used for full-length sequencing of Beet western yellows virus (BWYV-USA). Reverse-transcriptase polymerase chain reaction (RT-PCR) products used in the cloning and sequencing of BWYV-USA are shown. Sequences of primers (names in italic) are given in Table 3. Their localization is shown along the genome, position 1 and 5,666 being first and last nucleotide of the viral sequence. Sequences of the 10 clones and of the $5^{\prime}$ and $3^{\prime}$ rapid amplification of cDNA ends (RACEs) were aligned using ContigManager (DNAsis package, Hitachi). The putative open reading frames are boxed with their numbering and are stacked according to their three reading frame registers. 
toms of BWYV-USA on Montia perfoliata were severe (reddening of the leaves), whereas BMYV-2ITB did not induce any symptoms on this host (data not shown). The TuYV-FL1 lettuce isolate did not cause yellowing of sugar beet, and the TuYV-Col rape isolate failed to infect sugar beet. One of the hypotheses explaining this gradation of host response could be that host resistance mechanisms such as post-transcriptional gene silencing (PTGS) may be suppressed by the P0 of BWYVUSA, BChV, and BMYV $(24,25)$. Perhaps suppression of silencing is delayed upon TuYV-FL1 infection. PTGS may be induced early against TuYV inoculation in sugar beet, preventing infection altogether.

Spergula arvensis and Spinacia oleracea have been shown to be common hosts for the poleroviruses used in our study. Analysis of the host range revealed that BWYV-USA exhibits a much more extensive host range than any of the poleroviruses in this study, with the possible exception of TuYV-FL1. In fact, with very few exceptions, the host range of BWYV-USA is a composite of the host ranges of $\mathrm{BChV}$ and BMYV. One exception is that $C$. pepo is highly susceptible to BMYV-2ITB but not for BWYV-USA. In addition, Chenopodium capitatum is susceptible to BChV but not to BWYV-USA or the other poleroviruses tested, whereas Capsella bursa-pastoris, an important diagnostic host in the United States, is susceptible to BWYV-USA but not BChV (Table 1), making these two plant species suitable hosts for differentiating BWYVUSA from BChV. We have been able to show that BWYV-USA can transiently infect Asteraceae spp. such as L. sativa (var. batavia) when 10-day-old seedlings were inoculated. ELISA values decreased between 3 and 6 wpi to background levels, possibly indicating a recovery phenomenon similar to that described by Ratcliff et al. (28).

Preliminary epidemiological studies indicated that BWYV-USA was not detected in symptomatic sugar beet samples collected in France and England (M. Stevens unpublished). In contrast, $\mathrm{BChV}$ and BWYV-USA were readily detected in American samples, and doubly infected plants were identified (39). Dot hybridization and RT-PCR procedures showed that BMYV could not be detected in American sugar beet samples. By analyzing 11 sugar beet samples collected in Colorado and California by RT-PCR, 7 samples were found to be infected with $\mathrm{BChV}$ and 4 with BWYV-USA but not with BMYV, confirming earlier results. More epidemiological studies are needed to confirm the distribution and prevalence of the two species in the western United States. Additionally, an extensive host range study of BWYVUSA in American endemic weeds is warranted and would provide increased knowledge of virus reservoirs, especially those plant species belonging to the wild cucurbits. The host range of BWYV has not been examined since its initial characterization in $1960(6,7)$.

Because cross protection typically occurs between related viruses and strains, it is used as a valuable criterion to demarcate virus species. The extent of crossprotection usually correlates with the degree of genetic relatedness between protecting and challenging virus strains (26)
A

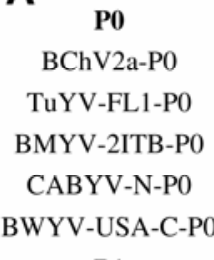

P1

BChV2a-P1

TuYV-FL1-P1

BMYV-2ITB-P1

CABYV-N-P1

BWYV-USA-C-P1

P2

BChV2a-P2

BMYV-2ITB-P2

CABYV-N-P2

BWYV-USA-C-P2
TuYV-FL1-P2

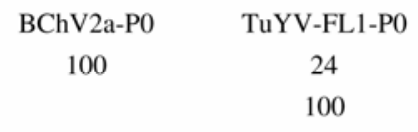

BChV2a-P1

100

BChV2a-P2

100

B

P3 (CP)
BChV2a-P3
TuYV-FL1-P3
BMYV-2ITB-P3
BWYV-USA-C-P3
P5 (RT)
BChV2a-P5
TuYV-FL1-P5
BMYV-2ITB-P5
BWYV-USA-C-P5

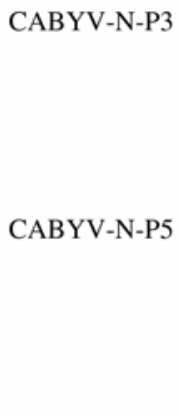

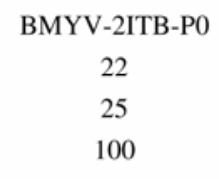
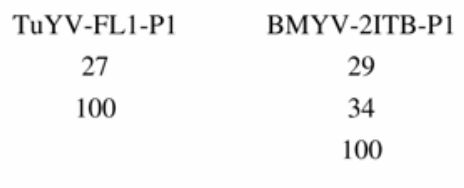
TuYV-FL1-P2
57
100
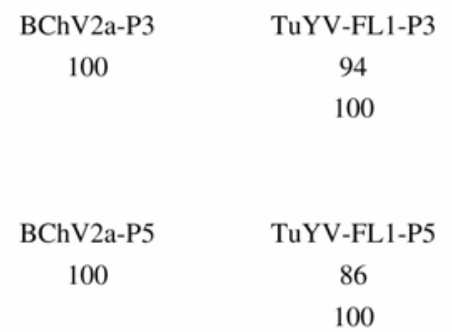

BChV2a-P5
100

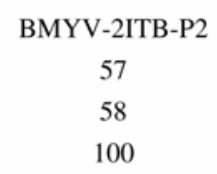

CABYV-N-P0
20
24
46
100

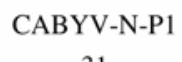

31

38

48

100

CABYV-N-P2

58

60

66

100

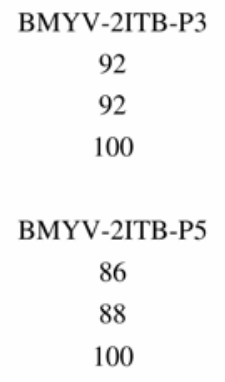

BWYV-USA-C-P0
19
26
46
52
100
BWYV-USA-C-P1
32
40
53
60
100
BWYV-USA-C-P2
56
60
69
72
100

BWYV-USA-C-P3
91
92
94
100
BWYV-USA-C-P5
$\mathbf{8 6}$
$\mathbf{8 8}$
$\mathbf{8 9}$
100

Fig. 3. A, Pairwise comparisons of the deduced nonstructural beet polerovirus proteins, including Cucurbit aphid-borne yellows virus (CABYV). Numbers indicate percent identity between amino acid sequences measured by using ClustalX. Numbers in boldface are the identities between Beet western yellows virus (BWYV)-USA and the other poleroviruses and classified from the lowest to the greatest percentage. B, Pairwise comparisons of the deduced structural beet Polerovirus proteins. Numbers indicate percent identity between amino acid sequences measured by using ClustalX. Numbers in boldface are the identities between BWYV-USA and the other poleroviruses and classified from the lowest to the greatest percentage. 
and has been shown to occur for serotypes of BYDV (46). Moreover, cross-protection minimizes the occurrence of mixed infection of related virus strains. Our experi- ments showed that no cross-protection occurred between BWYV-USA and BMYV when BMYV was used as challenging virus, regardless of the interval between the inoculations. This feature provides further evidence to support the view that BWYV-USA and BMYV are distinct Polerovirus spp.
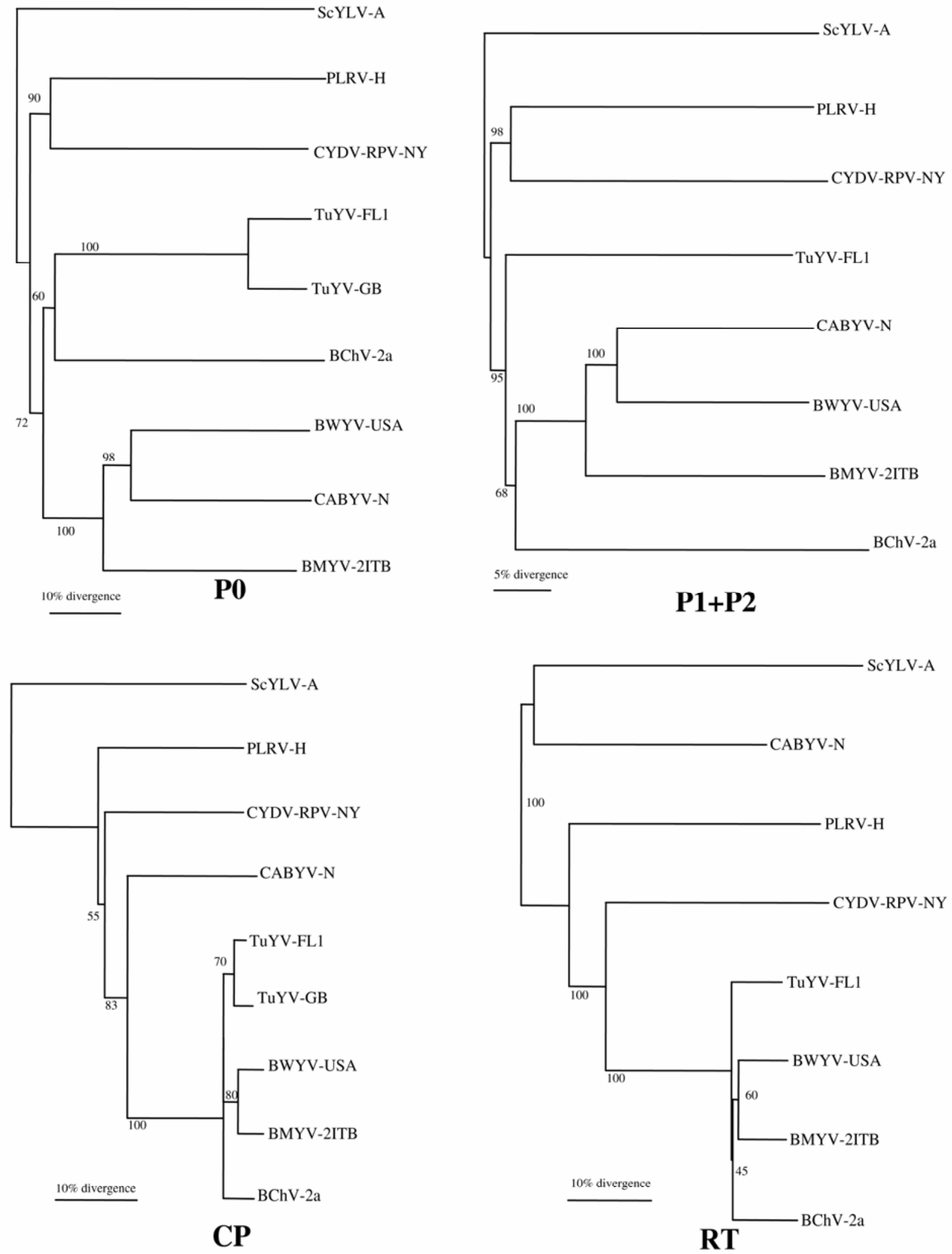

Fig. 4. Phylogenetic analysis of aligned protein sequences from members of the Polerovirus genus. Neighbor-joining phylogenetic trees of proteins encoded in the $5^{\prime}(\mathrm{P} 0, \mathrm{P} 1+\mathrm{P} 2)$ and $3^{\prime}$ (coat protein [CP] and readthrough [RT]) portions of various Polerovirus genomes have been constructed using ClustalX. Bootstrap percentage values based on 1,000 replicates are shown. The strains used to draw these dendrograms are the following (acronym, GenBank accessions): Sugarcane yellow leaf virus (ScYLV-A, AF157029), Potato leafroll virus (PLRV-H, Y07496), Cereal yellow dwarf virus (CYDV-RPV-NY, L25299), Cucurbit aphid borne yellows virus (CABYV-N, X76931), Beet western yellows virus-FL1 (TuYV-FL1, X13063), Beet mild yellowing virus (BMYV-2ITB, X83110), Beet chlorosis virus (BChV-2a, AF352024), and Turnip yellows virus (TuYV-GB, AF168608, AF167486). 
Phylogenic and evolutionary relationships. The BWYV-USA sequence data provides valuable information to classify definitively this virus as a different species than the Asteraceae- or Brassicaceaeinfecting poleroviruses which, until recently, were classified under the generic name BWYV and then reclassified as TuYV (18). Comparison of P1 and P2 of BChV-2a and TuYV-FL1 with the same region of BWYV-USA showed less than 40 and $60 \%$ homology, respectively, confirming evidence from biological and serological studies that BWYV-USA is a distinct Polerovirus sp. Previous data have shown that BMYV-2ITB was genetically similar to CABYV within the P0 and replication complex (13). Similarly, the 5' encoded proteins of BWYV-USA are more closely related to those of CABYV than to $\mathrm{P} 0, \mathrm{P} 1$, and $\mathrm{P} 2$ of BMYV-2ITB.

The sequence at the $5^{\prime}$ end of BWYVUSA has shown that it also is more closely related to that of CABYV, suggesting a common ancestor for BWYV-USA, BMYV, and CABYV. All three species may have arisen from a similar evolutionary mechanism by intragenus recombination events within the Polerovirus genus. Clustering of BWYV-USA and BMYV CP shows closely related branches, which is not surprising for two viruses that share numerous biological properties. The topology of the phylogenetic tree for the readthrough (RT) protein was similar to that of $\mathrm{CP}$, except the length of the branches were longer between the beet poleroviruses than other members of Luteoviridae.

These phylogenetic trees suggest that the genomes of the different poleroviruses have evolved by recombination events between members of different Luteoviridae ancestral groups (22), with BWYVUSA displaying an evolution similar to BMYV but different from BChV. The importance of recombination has been described for the emergence of new Luteoviridae species and variants $(5,19,22,41)$, and RNA recombination among the members of Luteoviridae appears to have occurred at two levels. Initially, recombination led to the two major genera (Luteovirus and Polerovirus), with secondary recombination events between Polerovirus-Polerovirus and LuteovirusPolerovirus ancestors after the divergence of the two groups (21). This approach could be used to explain the differences in origin of BMYV and BWYV-USA. Subsequent recombination events between a CABYV-like and beet Polerovirus-like ancestor present on the two continents may have occurred, donating the 5' ORF 0 and replicase complex and the $3^{\prime}$ structural genes, respectively. BWYV-USA may have diverged from a lost ancestor of both BMYV and BWYV-USA in the United States. Ancestral BMYV might have been less competitive and was eventually lost, perhaps due to the wide host range and adaptability of BWYV-USA compared with that of BMYV. A wild cucurbit could have been the common host for these ancestors because we have shown that both BMYV and BWYV-USA are able to infect a cucurbit species.

Interestingly, the evolution of $\mathrm{BChV}$ is different. The American and European isolates of $\mathrm{BChV}$ are quite similar, especially in their $5^{\prime}$ part (14). This remarkable sequence similarity could have resulted from the evolution of $\mathrm{BChV}$ at its point of origin either in Europe or in America in one of the native Beta vulgaris parents and then spread rapidly by the exchange of plant breeding material and by an efficient vectoring ability. These poleroviruses may have now reached an optimum fitness, giving the genetic stability observed between European and American BChV isolates. American SCYLV isolates (21) share the same properties of genomic stability (except for the P2-NCR region). BWYV-USA and BMYV provide a valuable model for studying speciation and evolution of poleroviruses because they have developed via parallel mechanisms, originating from two geographically distinct origins, and display close sequence organization as a result of host and vector selection, with a biological fitness well adapted to the sugar beet environment.

Altogether, these properties prove that BWYV-USA is a distinct virus species of the Polerovirus genus and is related to BMYV and BChV. Therefore, the three distinct Polerovirus spp. that do infect sugar beet and induce the mild yellowing disease alone or as a viral complex are BWYV, BMYV, and BChV. It is proposed herein that the name BWYV should be retained for all sugar beet-infecting isolates that share similar biological and molecular properties with the BWYV-USA isolate described in the present study. Finally, this proposal will be presented to the ICTV for ratification in order to clarify the nomenclature of the beet poleroviruses within the genus Polerovirus, family Luteoviridae. Such a declaration will reduce much of the remaining confusion associated with virus nomenclature within the genus Polerovirus.

\section{ACKNOWLEDGMENTS}

We thank the Institut Technique de la Betterave (ITB) for funding the epidemiological work done on French sugar beet samples and SES-Advanta company for funding S. Hauser's thesis work on beet Polerovirus variability. M. Stevens is funded by the British Beet Research Organisation at Broom's Barn Research Center, a Department of Rothamsted Research, which receives grant-aided support from the Biotechnology and Biological Sciences Research Council. Research at the USDAARS in Salinas, CA was funded in part through the California Beet Growers' Association Industry Research Committee and the Western Sugar Company-Grower Joint Research Committee.

\section{LITERATURE CITED}

1. Bjorling, K., and Nilsson, B. 1966. Observation on host range and vector relations of Beet mild yellowing virus. Socker 21:1-14.

2. d'Arcy, C. J., and Mayo, M. A. 1997. Proposals for changes in luteovirus taxonomy and nomenclature. Arch. Virol. 142:1285-1287.

3. d'Arcy, C. J., Torrance, L., and Martin, R. R. 1989. Discrimination among luteoviruses and their strains by monoclonal antibodies and identification of common epitopes. Phytopathology 79:869-873.

4. de Miranda, J. R., Stevens, M., de Bruyne, E., Smith, H. G., Bird, C., and Hull, R. 1995. Sequence comparison and classification of beet luteovirus isolates. Arch. Virol. 40:2183-2200.

5. Domier, L. L., McCoppin, N. K., Larsen, R. C., and d'Arcy, C. J. 2002. Nucleotide sequence shows that Bean leafroll virus has a Luteovirus-like genome organization. J Gen. Virol. 83:1791-1798.

6. Duffus, J. E. 1960. Radish yellows: a disease of radish, sugar-beet, and other crops. Phytopathology 50:389-394.

7. Duffus, J. E. 1961. Economic significance of Beet western yellows (radish yellows) on sugar beet. Phytopathology 51:605-607.

8. Duffus, J. E. 1964. Host relationship of Beet western yellows virus strains. Phytopathology 54:736-768.

9. Duffus, J. E. 1973. The yellowing viruses of beet. Adv. Virus Res. 18:347-386.

10. Duffus, J. E., and Russell, G. E. 1970. Serological and host range evidence for the occurrence of Beet western yellows virus in Europe. Phytopathology 60:1199-1202.

11. Felsenstein, J. 1989. PHYLIP-Phylogeny interference package (version 3.2). Cladistics 5:164-166.

12. Fenner, F. 1976. The classification and nomenclature of viruses: second report of the International Committee on Taxonomy of Viruses. Intervirology 7:1-115.

13. Guilley, H., Richards, K. E., and Jonard, G. 1995. Nucleotide sequence of Beet mild yellowing virus RNA. Arch. Virol. 140:11091118.

14. Hauser, S., Stevens, M., Beuve, M., and Lemaire, O. 2002. Biological properties and molecular characterization of Beet chlorosis virus (BChV). Arch. Virol. 147:745-762.

15. Hauser, S., Stevens, M., Mougel, C., Smith, H. G., Fritsch, C., Herrbach, E., and Lemaire, O 2000. Biological, serological and molecular variability suggest three distinct Polerovirus species infecting beet or rape. Phytopathology 90:460-466.

16. Lemaire, O., Herrbach, E., Stevens, M., Bouchery, Y., and Smith, H. G. 1995. Detection of sugar beet-infecting Beet mild yellowing luteovirus isolates with a specific RNA probe. Phytopathology 85:1513-1518.

17. Liu, H. Y., Wisler, G. C., Sears, J. L., and Duffus, J. E. 1999. Beet chlorosis virus-a new luteovirus affecting sugarbeet. J. Sugar Beet Res. 36:69.

18. Mayo, M. A. 2002. ICTV at the Paris ICV: results of the plenary session and the binomial ballot. Arch. Virol. 147:2254-2260.

19. Mayo, M. A., and Miller, W. A. 1999. The structure and expression of luteovirus genomes. In: The Luteoviridae. H. G. S. a. H Barker, ed. CAB International, Wallingford, UK.

20. Mayo, M. A., and Ziegler-Graff, V. 1996. Molecular biology of luteoviruses. Adv. Virus Res. 16:413-460.

21. Moonan, F., and Mirkov, T. E. 2002. Analyses of genotypic diversity among north, south and central American isolates of Sugarcane yellow leaf virus: evidence for Colombian origins and for intraspecific spatial phylogenetic variation. J. Virol. 76:1339-1348.

22. Moonan, F., Molina, J., and Mirkov, T. E. 2000. Sugarcane yellow leaf virus: an emerging virus that has evolved by recombination between luteoviral and poleroviral ancestors. 
Virology 269:156-171.

23. Moury B., Desbiez C., Jacquemond M., and Lecoq, H. 2006. Genetic diversity of plant virus populations: towards hypothesis testing in molecular epidemiology. Adv. Virus Res. 67:49-87.

24. Pazhouhandeh, M., Dieterle, M., Marrocco, K., Lechner, E., Berry, B., Brault, V., Hemmer, O., Kretsch, T., Richards, K. E., Genschik, P., and Ziegler-Graff, V. 2006. F-box-like domain in the Polerovirus protein $\mathrm{P0}$ is required for silencing suppressor function. Proc. Natl. Acad. Sci. USA 103:1994-1999.

25. Pfeffer, S., Dunoyer, P., Heim, F., Richards, K. E., Jonard, G., and Ziegler-Graff, V. 2002. P0 of Beet western yellows virus is a suppressor of post-transcriptional gene silencing. J. Virol. 76:6815-6824

26. Ponz, F., and Bruening, G. 1986. Mechanisms of resistance to plant viruses. Annu. Rev. Phytopathol. 24:355-381.

27. Rabenstein, F., Graichen, K., Proll, E., Herrbach, E., and Lemaire, O. 1995. Detection of a second distinct strain of Beet western yellows luteovirus in oilseed rape using monoclonal antibodies. Züchtungsforschung, Ber. Bundesanst. Züchtungsforsch. Kulturpflanzen 1:137140.

28. Ratcliff F., Harrison B. D., and Baulcombe, D. C. 1997. A similarity between viral defense and gene silencing in plants. Science 5318:1558-1560.

29. Roland, G. 1936. Recherches sur la jaunisse de la betterave et quelques observations sur la mosaique de cette plante. Sucr. Belge 55:213-293.

30. Russell, G. E. 1958. Sugarbeet yellows: a preliminary study of the distribution and inter- relationships of viruses and virus strains found in East Anglia, 1955-1957. Ann. Appl. Biol. 46:393-398.

31. Russell, G. E. 1965. The host range of some English isolates of beet yellowing viruses. Ann. Appl. Biol. 55:245-252.

32. Russell, G. E., and Duffus, J. E. 1970. An aphid-transmitted yellowing virus disease of lettuce in England. Plant Pathol. 19:148-149.

33. Saiki, R. K., Gelfand, D. H., Stoffel, S., Sharf, S. J., Higuchi, R., Horn, G. T., Mullis, K. B., and Erlich, H. A. 1988. Primer-directed enzymatic amplification of DNA with a thermostable DNA polymerase. Science 239:487-491.

34. Schliephake, E., Graichen, K., and Rabenstein, F. 2000. Investigations on the vector transmission of the Beet mild yellowing virus (BMYV) and the Turnip yellows virus (TuYV). Z. Pflanzenkrankh. Pflanzenschutz 107:81-87.

35. Smith, H. G., Barker, I., Brewer, G., Stevens, M., and Hallsworth, P. B. 1996. Production and evaluation of monoclonal antibodies for the detection of Beet mild yellowing luteovirus and related strains. Eur. J. Plant Pathol. 102:163-169.

36. Smith, H. G., and Hinckes, J. A. 1985. Studies on Beet western yellows virus in oilseed rape (Brassica napus ssp. oleifera) and sugar beet (Beta vulgaris). Ann. Appl. Biol. 107:473-484.

37. Stevens, M., Freeman, B., Liu, H-Y., Herrbach, E., and Lemaire, O. 2005. Beet poleroviruses: close friends or distant relatives? Mol. Plant Pathol. 6:1-9.

38. Stevens, M., Liu, H.-Y., and Lemaire, O. 2006. The viruses. Pages 256-285 in: The Sugar Beet Book. A. P. Draycott, ed. Blackwells Publishing, Oxford, UK.
39. Stevens, M., Patron, N. J., Dolby, C. A Weekes, R., Hallsworth, P. B., Lemaire, O. and Smith, H. G. 2005. The distribution and properties of geographically distinct isolates of sugar beet yellowing viruses. Plant Pathol. 54:100-107.

40. Stevens, M., Smith, H. G., and Hallsworth, P. B. 1994. The host range of beet yellowing viruses among common arable weed species. Plant Pathol. 43:579-588.

41. Stuart, G. W., Moffett, P. K., and Bozarth, R. F. 2006. A comprehensive open reading frame phylogenetic analysis of isometric positive strand ssRNA plant viruses. Arch Virol. 151:1159-1177.

42. Thompson, J. D., Gibson, T. J., Plewniack, F., Jeanmougin, F., and Higgins, D. G. 1997. The ClustalX windows interface: flexible strategies for multiple sequence alignment aided by quality analysis tools. Nucleic Acids Res. 24:48764882 .

43. van Regenmortel, M. H. V., Bishop, D. H. L., Fauquet, C. M., Mayo, M. A., Maniloff, J., and Calisher, C. H. 1997. Guidelines to the demarcation of virus species. Arch. Virol. 142:1505 1518.

44. Veidt, I., Lot, H., Leiser, M., Scheidecker, D., Guilley, H., Richards, K., and Jonard, G. 1988. Nucleotide sequence of Beet western yellows virus RNA. Nucleic Acids Res. 16:9917-9932.

45. Watson, M. A. 1952. Beet yellows virus and other yellowing virus diseases of sugar beet. Pages 157-167 in: Rothamstedt Exp. Stn. Rep. 1951.

46. Wen, F., Lister, R. M., and Fattouh, F. A. 1991 Cross-protection among strains of Barley yel low dwarf virus. J. Gen. Virol. 72:791-799. 